\begin{abstract}
OBJECTIVE: To understand the role of apoptosis through Fas/Fas ligand (FasL) interaction in the pathogenesis of silicosis, we examined the expression of Fas antigen, FasL and apoptosis in bronchoalveolar lavage fluid lymphocytes obtained from patients with silicosis.

Materials and methods: Ten patients with silicosis, and 10 healthy controls were studied. Non-adherent cells were separated and analysed by cytometry for the expression of Fas antigen, FasL, and the coexpression of Fas/FasL. By double staining, we studied the FasL expression on CD4, CD8, CD56 and CD45RO-positive cells. DNA fragmentation was investigated by the terminal $\operatorname{deoxy}(d)$ UTP nick end labelling (TUNEL) method.

Results: We have found Fas and FasL expression in silicosis patients to be significantly higher than those in healthy controls. Interestingly, 6-18\% of lymphocytes from silicosis patients co-expressed Fas and FasL. In silicosis patients, FasL was highly expressed on $\mathrm{CD}^{+}, \mathrm{CD}^{+} 6^{+}$and $\mathrm{CD}^{4} 5 \mathrm{RO}^{+}$bronchoalveolar lavage cells. Fas antigen expressing cells showed DNA fragmentation characteristic for apoptosis.

Conclusion: FasL was significantly expressed on cytotoxic effector and memory cells. The Fas/FasL system is implicated in the inflammatory process observed in silicosis patients.
\end{abstract}

Key words: Silicosis, Inflammation, Fas, Fas ligand

\section{Expression of Fas antigen and Fas ligand in bronchoalveolar lavage from silicosis patients}

\author{
Agnès Hamzaoui ${ }^{1,2}$, Jamel Ammar ${ }^{1,2}$, Hédia Graïri ${ }^{1,2}$ \\ and Kamel Hamzaoui ${ }^{2, C A}$
}

${ }^{1}$ Pneumology Hospital A. Mami, Department of Respiratory Diseases, Ariana, Tunisia; ${ }^{2}$ Homeostasis and Cell Dysfunction Unit Research 99/UR/08-40, Medicine University of Tunis, 15 Rue Djebel Lakhdar, 1007 Tunis, Tunisia

\author{
${ }^{\mathrm{CA}}$ Corresponding Author \\ Fax: + 21671569427 \\ E-mail: Kamel.Hamzaoui@fmt.rnu.tn
}

\section{Introduction}

Silicosis is characterized by pulmonary lesions and various immunological abnormalities such as hypergammaglobulinaemia and the appearance of autoantibodies that are in some cases associated with clinical autoimmune manifestations. ${ }^{1,2}$ However, the mechanisms involved in the occurrence of immunodysfunction induced by silica compounds have not yet been determined. Silica compounds such as chrysotile, crocidolite anthophyllite, act as superantigens to activate human $\mathrm{T}$ cells polyclonally in vitro. ${ }^{3}$ Silica compounds have been found to induce an increase in intracellular calcium concentrations, ${ }^{4,5}$ enhancement of interleukin (IL)-2 secretion and activation of particular T-cell receptor $\mathrm{V} \beta_{5.3}$ in human peripheral blood $\mathrm{T}$ cells. ${ }^{6,7}$

It has been reported that serum levels of the soluble Fas (sFas) molecule were elevated in silicosis patients with no clinical symptoms of autoimmune diseases such as sclerotic skin, Raynaud's phenomenon, or arthralgia. ${ }^{8}$ The sFas message derived from peripheral blood mononuclear cells was dominantly expressed in these patients. ${ }^{9}$ Based on these investigations, dysregulation of the Fas-mediated apoptotic pathway may play an important role in the pathogenesis of the immunological abnormalities found in silicosis. In addition, it has been reported that silicone-containing macrophages prevent activationinduced cell death in murine lymphocytes. ${ }^{10}$ These results have led us to consider that it may be difficult for the $\mathrm{T}$ lymphocytes in patients with silicosis to proceed into apoptosis mediated by the Fas-related pathway. Moreover, based on previous results, which demonstrated that silica compounds act as superantigens against human $\mathrm{T}$ cells, ${ }^{6}$ these $\mathrm{T}$ cells might include self-recognizing clones. On the contrary, Smalley et al $^{11}{ }^{11}$ reported that the T-cell response to silicon dioxide is monocyte dependent and not a superantigen.

Recent studies have demonstrated the presence of Fas and FasL gene mutations in the $l p r$ and gld mice, which are used as a model of autoimmune diseases, resulting in defects in the apoptotic process. ${ }^{12,13}$ Recent results demonstrated a spontaneous occurrence of apoptosis in the inflammatory sites of rheumatoid arthritis in vivo and demonstrated that this process was mediated by Fas antigen in vitro. ${ }^{14-16}$ Therefore, it is suggested that the Fas/ FasL system may be involved in the pathogenesis of silicosis. In lung silicosis, mechanisms leading to lymphocyte activation are still poorly understood, and no data were reported about investigations in human bronchoalveolar lavage (BAL) of silicosis 
patients, which constitute an interesting way to explore in vivo the apoptosis pathway in silicosis.

We studied the expression of Fas antigen and FasL in BAL fluid lymphocytes from silicosis patients. To clarify whether apoptosis occurred in the Fas antigenpositive cells of silicosis, we also examined the relationship between Fas/FasL antigen expression and CD4, CD8, CD56 and CD45RO BAL lymphocytes. Our results demonstrated that FasL was expressed on BAL-CD 45RO ${ }^{+}$T cells and $\mathrm{CD} 56^{+}$cells. Our findings suggest that the Fas/FasL system may represent one of the mechanisms of apoptosis in BAL, and that it may be the consequence of silica dust activation in the lung.

\section{Patients and methods}

\section{Patients and sera}

Ten patients with silicosis were studied (seven smokers and three non-smoker men; 38-69 years; mean age, 54 years; average age, $48 \pm 7$ years) with no clinical symptoms of autoimmune diseases such as sclerotic skin, or arthralgia. Silicosis was assessed according to the International Labor Office criteria: patients experienced a heavy and prolonged occupational exposure to silica dust, and showed roentgenological and functional signs of silicosis. Ten healthy volunteers (all men; four smokers and six nonsmokers; average age, $25 \pm 2$ years) acted as controls. Informed consent had been obtained from patients and controls. The study was approved by the local Ethics Committee.

\section{$\mathrm{BAL}$ analysis}

The BAL procedure was performed mainly as described elsewhere. ${ }^{17}$ The cellular fraction was predominantly mononuclear ( $>90 \%$ ). BAL fluids were filtered through a single layer of sterile gauze (Sincab, Malmo, Sweden). After centrifugation ( $500 \mathrm{rpm}$ for 10 $\mathrm{min}$ ), the cell pellets were washed twice in phosphate-buffered saline. Alveolar macrophages were separated from lymphocytes by adherence to plastic (Costar, Cambridge, MA, USA) for $2 \mathrm{~h}$ at $37^{\circ} \mathrm{C}$ and 5\% $\mathrm{CO}_{2}$. Cell differential counts were determined by Wright-Giemsa staining. The results of BAL analysis of the aliquots are presented in Table 1. Calculations were made in duplicate and expressed as the mean \pm standard error of the mean. Cells were $>94 \%$ viable as determined by the trypan blue exclusion test.

The mean CD4/CD8 ratio in silicosis patients was (1.3 \pm 0.9 ; range, $1.2-1.8)$ significantly different compared with in healthy controls $(1.9 \pm 0.8$; range, $1.6-$ $2.3, p<0.05)$. Significant differences in the total cell count were observed between silicosis patients and healthy controls (Table 1).
Table 1. Characteristics of BAL analysis in silicosis patients and in healthy controls

\begin{tabular}{lcc}
\hline & Silicosis patients & Healthy controls \\
\hline Recovery (\%) & $74.8 \pm 7.3$ & $72.7 \pm 2.8$ \\
Total cell & $9.410^{6} \dagger$ & $12.610^{6}$ \\
Macrophage (\%) & $89.6 \pm 9.4$ & $87.5 \pm 2.3$ \\
Lymphocyte (\%) & $9.2 \pm 2.7$ & $11.7 \pm 0.6$ \\
Neutrophil (\%) & $1.6 \pm 0.7$ & $0.9 \pm 0.2$ \\
Eosinophil (\%) & $0.6 \pm 0.4$ & $0.7 \pm 0.3$ \\
CD4/CD8 ratio & $1.3 \pm 0.9^{\dagger}$ & $1.9 \pm 0.8$ \\
\hline
\end{tabular}

Data expressed as mean \pm standard eror of the mean.

$\dagger<0.05$ compared with healthy controls.

Lymphocytes were separated into $\mathrm{CD}^{+}$and $\mathrm{CD}^{+}$subsets by positive selection using coated magnetic beads (Dynabeads; Dynal, Oslo, Norway) as reported elswere. ${ }^{18}$ Briefly, cells were incubated with magnetic beads coated with an anti-CD4 monoclonal antibody $(\mathrm{mAb})$ at $4{ }^{\circ} \mathrm{C}$ for $1 \mathrm{~h}$ with rocking in 1 $\mathrm{ml}$ of RPMI 1640 medium plus 0.01\% human serum albumin (Bayer Corporation, Marseille, France). $\mathrm{CD}^{+}$cells were collected using a magnet, and the remaining cells were collected and improved again with an anti-CD8 ${ }^{+} \mathrm{mAb}$. To improve purity, the magnetic beads and attached cells were gently resuspended in $3 \mathrm{ml}$ of RPMI 1640 medium plus $0.01 \%$ human serum albumin, and $\mathrm{CD}^{+}$or $\mathrm{CD}^{+}$ cells were again collected with a magnet. The purity of the preparations obtained was for $\mathrm{CD}^{+}$cells $\left(\mathrm{CD}^{+}>94 \%, \mathrm{CD}^{+}<6 \%\right)$ and for $\mathrm{CD}^{+}$cells $\left(\mathrm{CD}^{+}>95 \%, \mathrm{CD}^{+}<5 \%\right)$.

\section{Immunohistochemical analysis}

The following mAbs were used: anti-CD3, anti-CD4, anti-CD8, anti-CD56 and anti-CD45RO (Sigma, Aldrich, Germany). Cytospins were prepared by adding $75 \mu \mathrm{l}$ of cell suspension into Shandon cytocentrifuge3 cups (Shandon Instruments, London, UK) and spun for $8 \mathrm{~min}$ at $500 \mathrm{rpm}$. We performed immunohistochemical double staining with each of the antibodies on the blocked cytospin slides. Cells preparations were incubated with the mAbs anti-Fas (UB2) and anti-FasL (NOK2). For anti-Fas detection an immunoperoxidase procedure was performed using the ABC kit (Vector Laboratories, Marseille, France), and anti-FasL was visualized by direct labelling with CY3 (Biological Detection Systems, Inc., Pittsburgh, PA, USA) for double staining as described in the following. Negative control studies were performed for each experiment by isotype-matched control mAb.

Following the first immunohistochemical staining, we performed immunohistochemical double staining with each of the following antibodies: anti-Fas, antiFasL, anti-CD3, anti-CD4, anti-CD8, anti-CD56 and anti-CD45RO (Dako, Marseille, France). After duplicate washing with phosphate-buffered saline, the slides were incubated with fluorescein isothiocya- 
nate-labelled anti-mouse goat immunoglobulin G (Dako) or visualized by the APAAP system (Dako).

Certain patients were also studied by cytofluorometric analysis. The lymphocyte fraction was gated and the percentage of Fas-positive cells or fluorescence intensity was studied. Cytofluorometric analysis, counting 1000 cells/sample, were performed on a fluorescence activated cell analyser (FACScan; Becton Dickinson) as we have reported elsewhere. ${ }^{19}$ Positive cells were determined by setting a threshold with reference to the relevant negative control.

\section{Detection of apoptosis by DNA nick end labelling (TUNEL)}

Terminal deoxy(d) UTP nick end labelling (TUNEL) was performed as described according to the method of Gavrieli et al., ${ }^{20}$ with few modifications. Nonadherent cells were adjusted to $1.2 \times 10^{6}$ cells $/ \mathrm{ml}$. Briefly, cell preparations were immersed in terminal deoxynucleotidyl transferase (TDT) buffer $(30 \mathrm{mM}$ of Trizma base, $\mathrm{pH} 7.2,140 \mathrm{mM}$ of sodium cacodylate, $1.0 \mathrm{mM}$ of cobalt chloride). TDT (0.3 units/ $\mu \mathrm{l})$ and biotinylated dUTP or digoxygenin-dUTP in TDT buffer were then added to the samples. The reaction was terminated by placing the slides in the TB buffer (300 mM of sodium chloride, $30 \mathrm{mM}$ of sodium citrate), and samples were visualized with the ABC kit (Vector Laboratories). Negative control studies were performed by omitting the TDT.

\section{Reverse transcription-polymerase chain reaction Southern blot analysis.}

We prepared total RNA $(6-12 \mu \mathrm{g})$ using $10^{7} \mathrm{BAL}$ lymphocytes obtained from four silicosis patients. In addition, $\mathrm{CD}^{+}{ }^{+}$and $\mathrm{CD}^{+}{ }^{+}$cells were prepared using the bead separation method described earlier. cDNA synthesis and polymerase chain reaction (PCR) were performed. Cells were stimulated with $10 \mathrm{ng} / \mathrm{ml}$ of phytohaemagglutinin P (Difco Laboratories, Detroit, MI, USA). Briefly, first-strand cDNAs were synthesized in a $20 \mu \mathrm{l}$ reaction mixture containing oligo(dT) primer using $1.0 \mu \mathrm{g}$ of total RNA. PCR was performed with primers specific for FasL $\left(5^{\prime}\right.$-primer, 5'-CGCCACCACTGCCTCCACTA-3'; 3'-primer, 5'CTTCCCCTCCATCATCACC A-3') or primers for $\beta$ actin ( $5^{\prime}$-primer, 5'-TACATGGCTGGGGTG21TGGAA3'; 3'-primer, 5'-AAGAGAGGCATCCTC-ACCCT-3') described elsewhere. ${ }^{21}$ Denaturing was performed at $94^{\circ} \mathrm{C}$ for $90 \mathrm{sec}$, annealing at $60^{\circ} \mathrm{C}$ for $90 \mathrm{sec}$, and extension at $72^{\circ} \mathrm{C}$ for $60 \mathrm{sec}$, for 30 cycles on a DNA thermal cycler (Perkin-Elmer, Norwalk, CT, USA). In the next step, 10\% of the PCR products (FasL, 492 base pairs; $\beta$-actin, 246 base pairs) was subjected to $2 \%$ agarose gel electrophoresis and hybridized with digoxygenin-labelled PCR product probe encoding FasL or $\beta$-actin genes as described elsewhere. ${ }^{22}$

\section{Statistical analysis}

Data are expressed as the mean \pm standard error of the mean. Statistical significance was calculated using the Mann-Whitney $U$-test for non-parametric data. $p<0.05$ denoted the presence of a statistical significant difference.

\section{Results}

\section{Fas antigen expression in BAL fluid cells}

We examined the expression of Fas antigen in BAL lymphocytes from silicosis patients and healthy controls (Fig. 1). The expression of $\mathrm{CD}^{+}$cells was $>$ $85 \%$ both in silicosis patients and in healthy controls. Staining with anti-Fas mAb showed that $21-37 \%$ of cells were positive for Fas antigen in BAL lymphocytes from silicosis patients (mean, 29.6\%). In healthy control BAL lymphocytes, only $6-14 \%$ of cells expressed Fas antigen (mean, 9.4\%).

\section{FasL expression in BAL fluid lymphocytes.}

In the next step, we examined the expression of FasL in BAL fluid lymphocytes (Fig. 1). The expression of FasL was analysed using anti-FasL mAb. Thirty-three per cent to $47 \%$ (mean, 39.1\%) of positively stained cells with anti-FasL mAb were detected in all BAL lymphocytes from silicosis patients. In contrast, there were very few FasL-positive cells in the BAL fluid lymphocytes from healthy controls $(<10 \%$; mean, 5.7\%).

Double staining with anti-Fas and anti-FasL mAbs (Fig. 1) also revealed that FasL-positive lymphocytes were occasionally observed in Fas-positive cells from healthy controls (2-5\%; mean, 4.3\%). Interestingly, $6-18 \%$ of lymphocytes co-expressed both Fas and FasL in silicosis patients (mean, 13.5\%).

\section{Apoptosis in BAL: lymphocytes and relationship with Fas-positive cells}

Apoptosis in silicosis patient BAL was investigated using the TUNEL method (Table 2). The number of apoptotic cells in silicosis patients was significantly higher $(23.2 \pm 3.9 \%)$ than that in healthy controls $(4.8 \pm 1.7 \%, p<0.05)$. DNA fragmentation was seen in $13-27 \%$ (mean, 19.1\%) of BAL Fas-positive cells. In contrast, $3-7 \%$ of Fas-positive cells in healthy controls were positive for TUNEL.

\section{FasL expression on T cells and natural killer cells in BAL}

Double staining was performed to determine the type of cells expressing FasL in BAL fluid. Expression of 


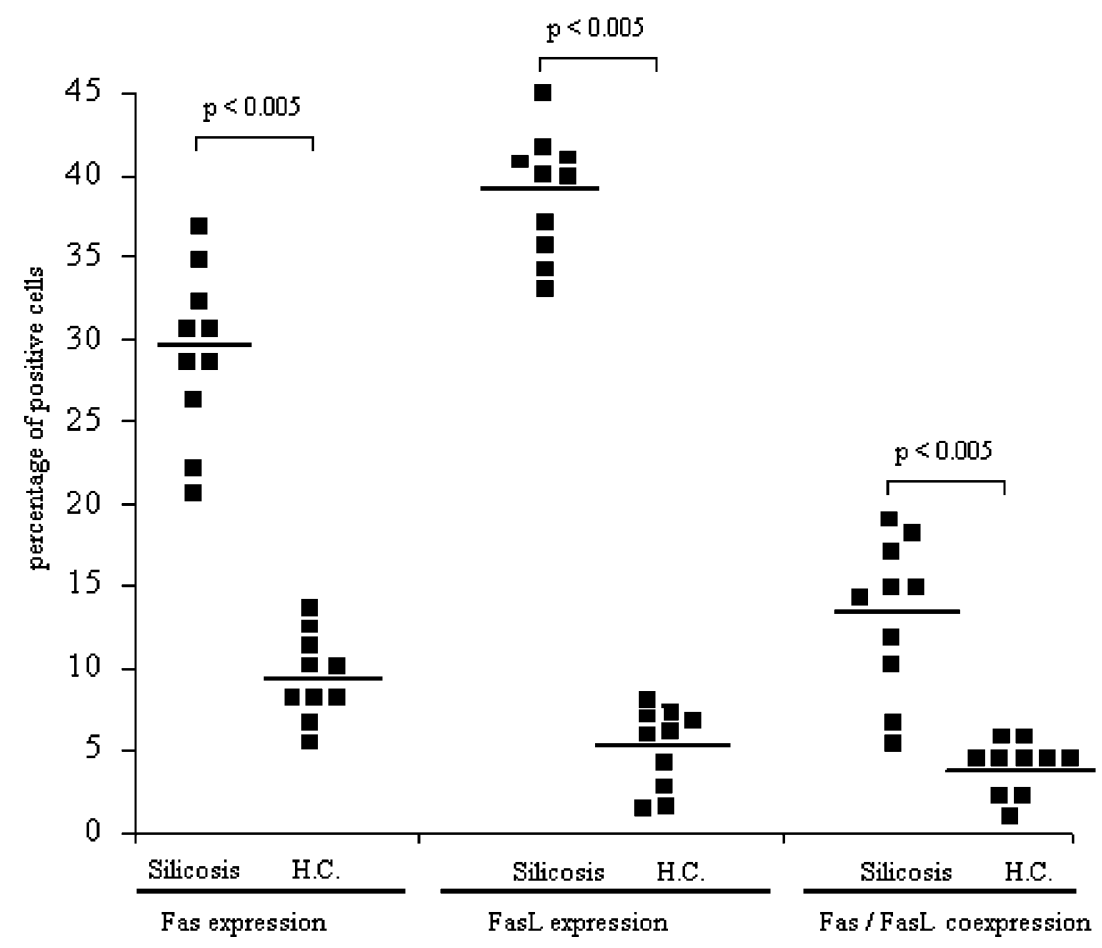

FIG. 1. Expression of Fas and FasL on BAL lymphocytes from silicosis patients and healthy controls (H.C.).

Table 2. The percentages of apoptosis in BAL mononuclear cells and Fas antigen expression

\begin{tabular}{lccc}
\hline Patients & Fas (\%) & Apoptosis (\%) & $\begin{array}{c}\text { DNA fragmentation } \\
\text { in Fas }^{+} \text {cells }\end{array}$ \\
\hline 1 & 22 & 25 & 18 \\
2 & 27 & 14 & 13 \\
3 & 37 & 23 & 19 \\
4 & 30 & 25 & 21 \\
5 & 35 & 19 & 16 \\
6 & 28 & 32 & 23 \\
7 & 23 & 27 & 20 \\
8 & 34 & 30 & 27 \\
9 & 29 & 13 & 12 \\
10 & 31 & 24 & 22 \\
\hline
\end{tabular}

FasL in silicosis patients was detected in $13-26 \%$ of $\mathrm{CD}^{+}$cells (mean, $19.3 \%$ versus $4.3 \%$ in healthy controls, $p<0.005)$, in $12-18 \%$ of $\mathrm{CD}^{2} 6^{+}$cells (mean, $16.4 \%$ versus $1.5 \%$ in healthy controls, $p<$ 0.005 ), and in $2-6 \%$ of $\mathrm{CD}_{45 \mathrm{RO}^{+}}$cells (mean, $4.2 \%$ versus 1.7 in healthy controls, $p<0.005$ ).

To confirm the expression of FasL in $\mathrm{CD}^{+}$or $\mathrm{CD}^{+} \mathrm{T}$ cells in the BAL by positive selection using antibody-coated magnetic beads, reverse transcription-PCR Southern blot analysis was performed using $\mathrm{CD}^{+}$or $\mathrm{CD}^{+}$cells separated from the BAL fluid lymphocytes. Both $\mathrm{CD}^{+}$and $\mathrm{CD}^{+}$cells from silicosis patients appeared to express FasL mRNA (Fig. 2).

\section{$\begin{array}{llll}1 & 2 & 3 & 4\end{array}$}

(A)

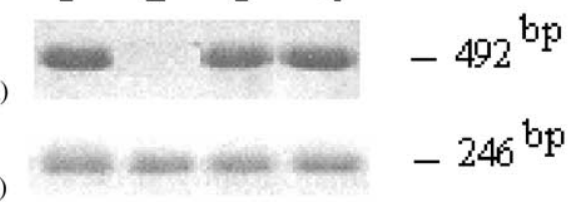

FIG. 2. FasL expression on CD4 and CD8 T cells. Lymphocytes from BAL were separated into $\mathrm{CD} 4^{+}$and $\mathrm{CD} 8^{+}$subsets by positive selection using antibody-coated magnetic beads. The expression of FasL (A) and $\beta$-actin (B) on phytohaemagglutinin (PHA)-stimulated BAL lymphocytes from silicosis patients (lane 1), PHA-stimulated BAL lymphocytes from healthy controls (lane 2), and separated $\mathrm{CD4}^{+}$(lane 3 ) and $\mathrm{CD}^{+}$(lane 4) $\mathrm{T}$ cells were examined by reverse transcription-PCR and followed Southern blot analysis as described in Materials and methods. bp, base pairs.

\section{Discussion}

The major finding of the present study was the increased expression of Fas and FasL-positive cells in silicosis BAL. Inflammatory $\mathrm{CD}^{+}, \mathrm{CD}^{+}, \mathrm{CD} 56^{+}$ and $\mathrm{CD}_{45 \mathrm{RO}^{+}}$cells in BAL from silicosis patients preferentially express FasL compared with BAL lymphocytes from healthy controls. During experimental silicosis, exposed inbred strains of mice to an aerosol of cristobalite silica showed accumulation of activated lymphocytes in alveolar spaces over months after exposure. ${ }^{23} \mathrm{CD} 4^{+}, \mathrm{CD}^{+}$, T-cell receptor $\gamma \delta^{+}$ and $\mathrm{CD} 56^{+}$lung cells produced increased levels of interferon- $\gamma,{ }^{23,24}$ suggesting a $\mathrm{Th}_{1}$-like response. The authors hypothesized that there is a reiterative 
amplification cycle in which macrophages with silica produce cytokines such as IL-12 and IL-18, which attract and activate lymphocytes. ${ }^{3}$ The $\mathrm{Th}_{1} / \mathrm{Th}_{2}$ imbalance is favourable to apoptosis dysregulation.

Previous studies revealed high serum sFas levels in silicosis patients without any clinical symptoms of autoimmune disease. ${ }^{25}$ Fas belongs to the TNF receptor family, and alternative mRNA splicing produces sFas molecules. ${ }^{26}$ In our silicosis group, sFas levels were increased in BAL fluid (data not shown). sFas molecules can protect cells from apoptosis, inhibiting Fas/FasL interactions. Dysregulation of the Fas gene may play an important role in the pathogenesis of the immunological abnormalities found in silicosis patients. ${ }^{27}$

The Fas/FasL system have been involved in the cell-mediated cytotoxicity. ${ }^{28}$ In the present study, we suggested the possibility that Fas/FasL interaction in lung silicosis is another pathway of cytotoxicity, since both Fas antigen and FasL were expressed in the lung lymphocytes. FasL expression was observed in CD56positive cells. On the contrary, Fas and FasL expression were co-expressed in lung lymphocytes. FasL tend to be highly expressed in silicosis lymphocytes, compared with healthy controls. The dysregulation in Fas/FasL expression is specific to inflammatory sites. Patients with rheumatoid arthritis expressed high level of Fas-positive cells in their synovial tissue. ${ }^{29}$ Fas-positive cultured synovial cells from rheumatoid arthritis patients undergo apoptosis with anti-Fas $\mathrm{mAb}$ in vitro. ${ }^{30}$

The expression of FasL by $\mathrm{CD}^{+}{ }^{+}$and $\mathrm{CD}^{+}{ }^{+} \mathrm{T}$ cells represented a way of cytotoxicity via the Fas/FasL interactions in silicosis patients. $\mathrm{CD}^{+}$and $\mathrm{CD}^{+}{ }^{+} \mathrm{T}$ cells, proliferating in silicosis lung inflammatory sites, could be accumulated by dust silica as antigen-driven mechanisms. FasL was highly expressed on $\mathrm{CD}^{4} 5 \mathrm{RO}^{+}$cells in silicosis patients. The expression of $\mathrm{CD} 45 \mathrm{RO}^{+}$cells indicate a proportion of $\mathrm{T}$ cells with a memory phenotype ${ }^{31}$ expressing the protein kinase $\mathrm{C}$ activation, ${ }^{32}$ and may explain the greater amount of IL- 2 and interferon- $\gamma$ secretion by $\mathrm{CD} 4^{+}$ cells. $^{33}$

In silicosis patients we think that $\mathrm{CD} 45 \mathrm{RO}^{+}$cells acted as killer effector cells. In our patients, a considerable proportion of $\mathrm{CD}_{4}{ }^{+} \mathrm{T}$ cells in $\mathrm{BAL}$ are already committed, without other antigenic stimulation, to differentiate to $\mathrm{Th}_{1}$-like cells. It has been reported that the proliferation of $\mathrm{CD} 45 \mathrm{RO}^{+}$T cells is accompanied by a striking increase in apoptotic activity. ${ }^{34}$ Such observation implies that primed $\mathrm{T}$ cells are eliminated at a high rate by apoptosis. The expression of CD45RO molecule was the result of an antigen stimulation or its equivalent that downregulates the CD45RA molecule. ${ }^{35}$ It has been reported that CD45RO and other similar epitopes are also expressed on $\mathrm{T}$ cells undergoing apoptosis following activation. ${ }^{36}$
An important percentage (19\%) of Fas-positive BAL cells showed DNA fragmentation detected by TUNEL. Furthermore, FasL-positive lymphocytes were observed around Fas-positive BAL cells in silicosis patients. These data suggest the possibility that apoptosis may occur through the interaction of Fas/ FasL. Interestingly, $13.5 \%$ of BAL lymphocytes coexpressed both Fas and FasL, suggesting that Fas/ FasL interactions may function in paracrine and autocrine mechanisms. This may be relevant to the abnormal immune responses in the inflammatory lung cells. However, our results did not exclude other apoptotic pathways, different from the Fas/FasL system.

In summary, the present data revealed that a number of activated $\mathrm{T}$ cells and natural killer cells infiltrating the BAL fluid from silicosis patients were activated in vivo. This suggests that the mechanism of elimination of certain Fas-positive cells involves apoptosis mediated by Fas/FasL interaction. Our study may help to expand our understanding of the inflammation process in silicosis.

ACKNOWLEDGEMENTS. This work was supported by a Grant-in-Aid for Scientific Research, 'Ministère de l'enseignement supérieur et de la recherche scientifique et de la technologie, direction de la recherche scientifique Tunisie'

\section{References}

1. Garn H, Friedetzky A, Davis GS, Hemenway DR, Gemsa D. Tlymphocyte activation in the enlarged thoracic lymph nodes of rats with silicosis. Am J Respir Cell Mol Biol 1997; 16: 309-316.

2. Ueki A, Isozaki Y, Tomokuni A, et al. Intramolecular epitope spreading among anti-caspase-8 autoantibodies in patients with silicosis, systemic sclerosis and systemic lupus erythematosus as well as in healthy individuals. Clin Exp Immunol 2002; 129: 556-561.

3. Ueki A, Kinugawa K, Hyodoh F, Kawakami Y, Sakagushi, Miyahara Y. The role of silica compounds in the autoimmune diseases accompanied by silicosis. Arch Complex Environ Studies 1996; 8: 53-59.

4. Kinugawa K, Ueki A, Yamaguchi M, Watanabe Y, Kawakami Y, Hyodah $\mathrm{F}$, Tsushima H. Activation of human $\mathrm{CD}^{+}{ }^{+} \mathrm{CD} 45 \mathrm{RA}^{+} \mathrm{T}$ cells by chrysotile asbestos in vitro. Cancer Lett 1992; 66: 99-106.

5. Watanabe Y, Yamaguchi M, Kawakami Y. Human CD ${ }^{+} \mathrm{CD}_{5} \mathrm{RA}^{+}$ lymphocytes can be stimulated by crocidolite, anthophyllite and amosite asbestos in vitro. Int J Oncol 1993; 2: 209-214.

6. Ueki A, Yamaguchi M, Ueki H, Watanabe Y, Ohsawa G, Kinugawa K, Kawakami Y, Hyodoh F. Polyclonal human T-cell activation by silicate in vitro. Immunology 1994; 82: 332-335.

7. Ueki A, Nakashima M, Kishimoto T, Sakaguchi H. Analysis of the expression of TCR V $\beta$ repertoires in patients with silicoses. $J$ Occup Health 1996; 3: 67-69.

8. Tomokuni A, Otsuki T, Isozaka Y, Ueki H, Kusaka M, Ueki A. Serum levels of soluble Fas ligand in patients with silicosis. Clin Exp Immunol 1999; 118: $441-444$.

9. Otsuki T, Sakaguchi H, Tomokuni A, et al. Soluble Fas mRNA is dominantly expressed in cases with silicosis. Immunology 1998; 94: $258-262$.

10. McDonald AH. Silicone-containing macrophages prevent activationinduced cell death in murine lymphocytes, Exp Biol 1999 [abstract $847.2]$

11. Smalley DL, Shanklin DR, Hall MF. Monocyte-dependent stimulation of human T cells by silicon dioxide. Pathobiology 1998; 66: 302-305.

12. Takahashi T, Tanaka M, Brannan CI, Jenkins NA, Copeland NG, Suda T, Nagata S. Generalized lymphoroliferative disease in mice caused by a point mutation in the Fas ligand. Cell 1994; 76: 969-976.

13. Adachi $M$, Watanabe-Fukungara $R$, Nagata $S$. Aberrant transcription caused by the insertion of an early transposable element in an intron of the Fas antigen gene of $l p r$ mice. Proc Natl Acad Sci USA 1993; 90: $1756-1765$ 
14. Nakajima T, Aone H, Hasunuma T, Yamamoto K, Shirai T, Hirohata K, Nishioka K. Apoptosis and functional Fas antigen in rheumatoid arthritis synoviocyte. Arthritis Rheum 1995; 38: 485-491.

15. Firestein GS, Yeo M, zvaifler NJ. Apoptosis in rheumatoid arthritis synovium. J Clin Invest 1995; 96: 1631-1638.

16. Hamzaoui K, Hamzaoui A, Zakraoui L, Chabbou A. Levels of soluble Fas/APO-1 in patients with Behçet's disease. Mediat Inflamm 1998; 7 : $111-114$

17. Hamzaoui A, Grairi H, Ammar J, Zekri S, Guemira F, Hamzaoui K. IL18 mRNA expression and IFNg induction in bronchoalveolar lavage from Behcet's disease. Clin Exp Rheumatol 2003; 21 (Suppl 30): 29-35.

18. Levesque MC, Haynes BF. Activated T lymphocytes regulate hyaluronan binding to monocyte CD 44 via production of IL-2 and IFN $\gamma$.J Immunol 2001; 166: $188-196$.

19. Hamzaoui K, Hamzaoui A, Hentati F, et al. Phenotype and functional profile of $\mathrm{T}$ cells expressing $\gamma \delta$ receptor from patients with active Behçet's disease. J Rheumatol 1994; 21: 2301-2306.

20. Gavrieli Y, Sherman Y, Ben Sasson SA. Identification of programmed cell death in situ via specific labeling of nuclear DNA fragmentation. $J$ Cell Biol 1992; 119: 493-501.

21. Kinoshita T, Imamura J, Nagai H, Shimotohno K. Quantification of gene expression over wide range by the polymerase chain reaction. Anal Biochem 1992; 206: 231-235.

22. Lanzillo J. Chemiluminiescent nuclei acid detection with digoxigeninlabeled probes: a model system with robes for angiotensin converting enzyme which detect less than one attomole of target DNA. Anal enzyme which detect less
Biochem 1991; 194: 45-53.

23. Davis GS, Holmes CE, Pfeiffer LM, Hemenway DR. lymphocytes, lymphokines and silicosis. J Environ Pathol Toxicol Oncol 2001; 1: $53-65$

24. Davis GS, Pfeiffer LM, Hemenway DR. Interferon- $\gamma$ production by specific lung lymphocyte phenotypes in silicosis in mice. Am J Respir Cell Mol Biol 2000; 22: 491-501.

25. Tomokuri T, Aikoh T, Matsuki T, et al. Elevated soluble Fas/APO-1 (CD95) levels in silicosis patients without clinical symptoms of autoimmune diseases or malignant tumors. Clin Exp Immunol 1997; 110: $303-309$

26. Cheng J, Zhou T, Liu C, et al. Protection from Fas-mediated apoptosis by soluble form of the Fas molecule. Science 1994; 263: 1759-1762.
27. Takemi OT, Akiko TO, Haruko SA, Fuminori HY, Masayasu KU, Ayako UE. Reduced expression of the inhibitory genes for Fas-mediated apoptosis in silicosis patients. J Occup Health 2000; 42: 163-168.

28. Kägi D, Vagnaux F, Ledermann B, et al. Fas and perforin pathway as major mechanisms of T cell-mediated cytotoxicity. Science 1994; 265 : $528-530$.

29. Ashara H, Hasumuna T, Kobata T, et al. Expression of Fas antigen and FasL in the Rheumatoid synovial tissue. Clin Immunol Immunopathol 1996; 81: $27-34$

30. Nakajima T, Aono H, Hasunuma T, Yamamoto $\mathrm{K}$, Shirai $\mathrm{T}$, Hirohata $\mathrm{K}$, Nishioka K. Apoptosis and functional Fas antigen in rheumatoid arthritis synoviocyte. Arthritis Rheum 1995; 38: 485-491.

31. Sakata-Kaneko S, Wakatsuki Y, Matsunaga Y, Usui T, Kita T. Altered Th1/ Th2 commitment in human $\mathrm{CD}^{+}{ }^{+} \mathrm{T}$ cells with ageing. Clin Exp Immunol 2000; 120: 267-273.

32. Robinson AT, Miller N, Alexander DR. CD3 antigen-mediated calcium signals and protein kinase $\mathrm{C}$ activation are higher in $\mathrm{CD} 45 \mathrm{RO}^{+}$than in CD 45RA ${ }^{+}$human T lymphocyte subsets. Eur J Immunol 1993; 23: $61-$ 68.

33. Brinkmann V, Kristofic C. Regulation by corticosteroids of Th1 and Th2 cytokine production in human $\mathrm{CD}_{4}^{+}$effector $\mathrm{T}$ cells generated from $\mathrm{CD}^{2} 5 \mathrm{RO}^{-}$and CD45RO ${ }^{+}$subsets. J Immunol 1995; 155: 3322-3328.

34. Oka S, Mori N, Matsuyama S, Takamori Y, Kubo K. Presence of B220 within thymocytes and its expression on the cell surface during apoptosis. Immunology 2000; 100: 417-423.

35. D'Imperio LMR, Alvarez JM, Furtado GC, Kipnis TL, Couthino A, Minoprio P. Ig-isotype patterns of primary and secondary $\mathrm{B}$ cell responses to Plasmodium chabaudi correlate with IFN-gamma and IL-4 cytokine production with CD45RB expression by $\mathrm{CD}^{+}$spleen cells. Scand J Immunol 1996; 43: 263-267.

36. Renno T, Attinger A, Rimoldi D, Hahne M, Tschopp J, MacDonald HR. Expression of B220 on activated $\mathrm{T}$ cell blasts precede apoptosis. Eur J Immunol 1998; 28: 540-547.

Received 20 May 2003

Accepted 2 June 2003 


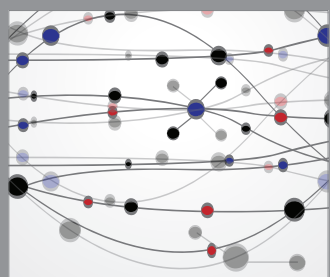

The Scientific World Journal
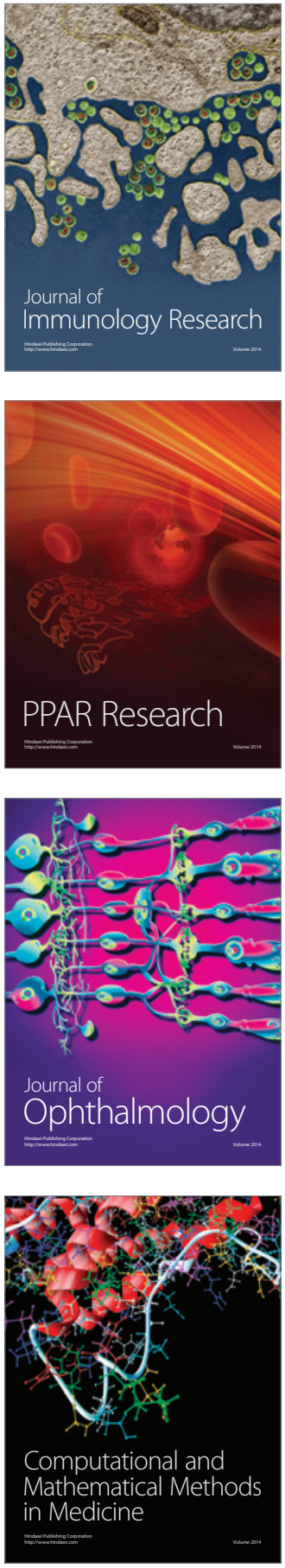

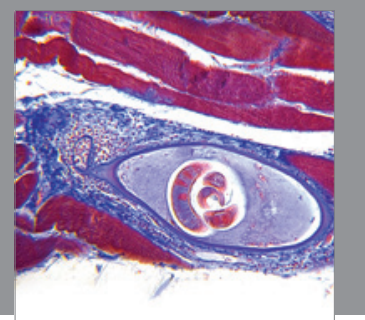

Gastroenterology

Research and Practice
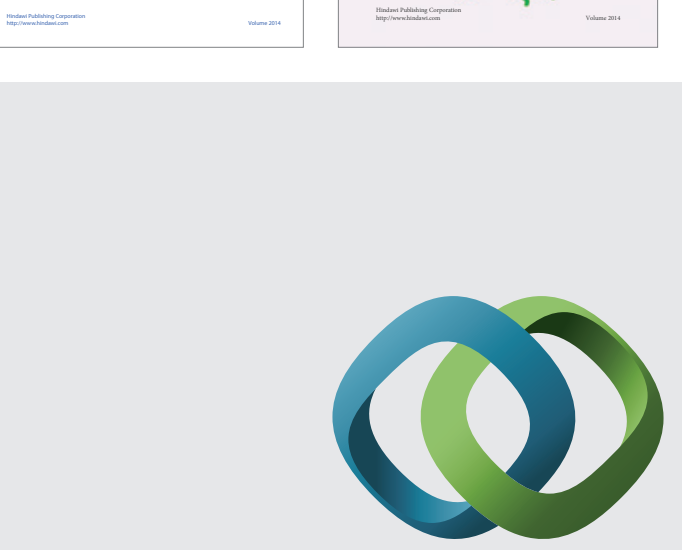

\section{Hindawi}

Submit your manuscripts at

http://www.hindawi.com
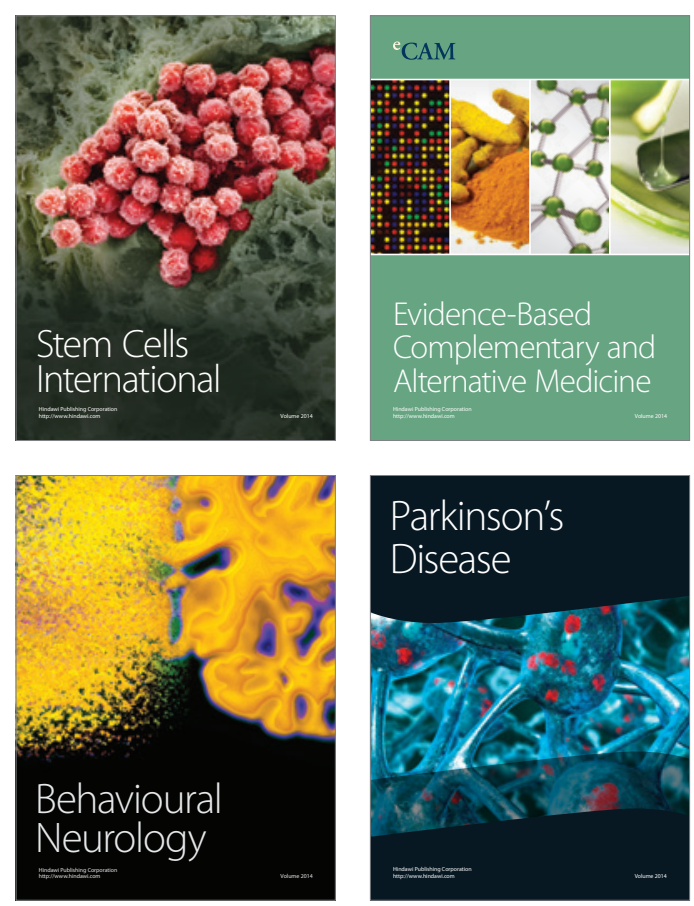

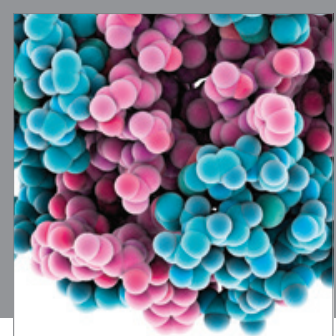

Journal of
Diabetes Research

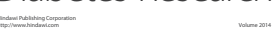

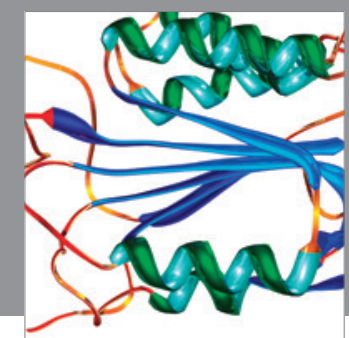

Disease Markers
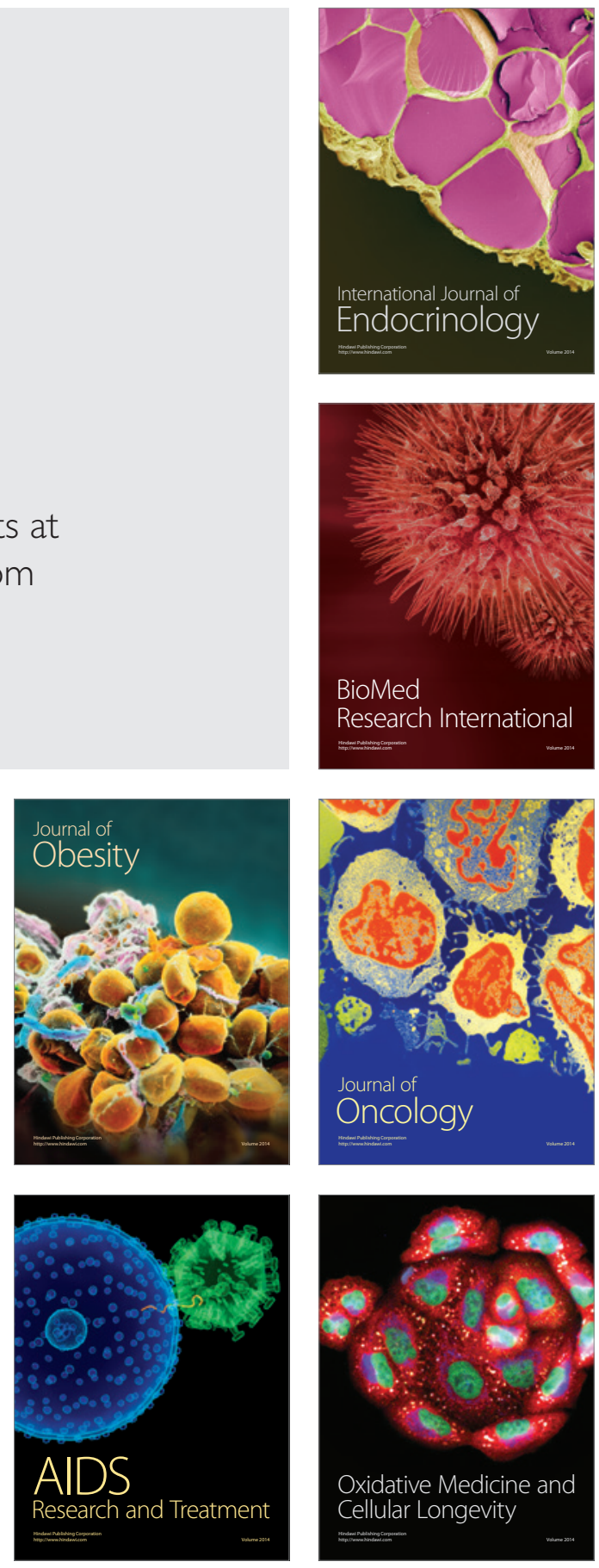